\title{
AKTIVITAS MENDONGENG MENGGUNAKAN MEDIA AUDIO VISUAL DALAM PEMBELAJARAN MORAL
}

\author{
Afifah Nur Hidayah ${ }^{1)}$, Nurhadija ${ }^{1}{ }^{*}$ \\ ${ }^{1}$ Jurusan PG-PAUD, Universitas Halu Oleo.Jln. H.E.A Mokodompit, Kendari 93232, Indonesia. \\ * Korespondensi Penulis. E-mail: nurhadija.dija96@gmail.com Telp: 082399185357
}

\begin{abstract}
Abstrak
Dongeng merupakan karya sastra nusantara yang banyak mengandung pembelajaran moral. Penggunaan dongeng sebagai pembelajaran moral di nilai sangat efektif untuk anak usia dini. Mendongeng mampu menarik perhatian anak untuk belajar dan metode mendongeng ini juga sangat mempermudah anak dalam memamahami nilai-nilai pembelajaran moral yang di sampaikan. Penggunaan metode ini akan lebih efektif jika menggunakan audio visual (video). Dengan menggunakan media audio-visual, pembelajaran moral dari dongeng akan meningkatkan ketertarikan anak untuk belajar dan tingkat pemahaman anak akan lebih tinggi karena tidak hanya menyapaikan dongeng dengan bercerita melainkan anak dapat melihat gambarnya secara secara langsung. Dengan adanaya gambar yang dapat langsung dilihat, maka anak dapat dengan mudah menerapkannya dalam kehidupan sehari-hari.
\end{abstract}

Kata Kunci : Dongeng, Pembelajaran Moral, Media Audio-Visual.

\section{STORYTELLING ACTIVITIES USING AUDIO VISUAL MEDIA IN MORAL LEARNING}

\begin{abstract}
The fairy tale is literary styles contain lots of moral learning. The use of fairy tales as moral value in learning is highly effective for early childhood. Storytelling is able to attract the attention of children to learn and the method of storytelling is also greatly simplify child in memamahami values in moral learning. The use of this method would be more effective if you are using audio visual (video). By using the audio-visual media, learning the moral of the tale is going to increase the interest of the child to the child's level of understanding and learning will be higher because not only menyapaikan the fairy tale with the story-telling but children can see the drawing is in directly. With adanaya images that can be directly viewed, then the child can easily apply it in everyday life.
\end{abstract}

Keywords: Fairy Tales, Moral Learning, Audio-visual Media.

\section{PENDAHULUAN}

Menurut UU no. 20 tahun 2003 tentang sistem pendidikan nasional pasal 3, pendidikan nasional berfungsi mengembangkan kemampuan dan membentuk karakter serta peradaban bangsa yang bermartabat dalam rangka mencerdasakan kehidupan bangsa. Pendidikan nasional juga bertujuan untuk berkembangnya potensi peserta didik agar menjadi manusia yang beriman dan bertaqwa kepada Tuhan Yang Maha Esa, berakhlak mulia, sehat, berilmu, cakap, kreatif, mandiri dan menjadi warga negara yang demokratis serta bertanggung jawab.

Dewasa ini sangat diperlukan pendidikan pada anak usia dini untuk pembentukan karakter dan moral anak, karena Indonesia sedang mengalami krisis karakter dan moral dalam diri anak bangsa. Pendidikan anak usia dini memerlukan perhatian yang sangat penting dari orang tua, ahli pendidikan, masyarakat dan pemerintah. Pendidikan anak usia dini, khususnya Taman Kanak-Kanak telah diselenggarakan sejak lama, yaitu sejak awal kemerdekaan. Di sekolah ini anak-anak usia 4-5 tahun atau 6 tahun mendapat tempat untuk mengembangkan potensinya dalam berbagai bentuk kegiatan.

Tentang fenomena degradasi moral yang melanda anak-anak sering dijumpai saat ini. Dilihat dari kacamata demografi Indonesia, penduduk usia remaja mencapai angka 30\%. Hal 
ini membuktikan bahwa jumlah remaja di Indonesia cukup besar. Sayangnya berdasaraka data Badan Narkotika Nasiobnal, justru 50-60 \% remaja malah menjadi pengguna narkoba. $48 \%$ dari jumlah tersebut merupakan pecandu sementara sisanya hanya mencoba. Kenyataan ini diperparah fakta lapangan bahwa $90 \%$ video porno yang beredar dalam beberapa tahun terakhir diperankan oleh remaja (Kapanlagi.com, 2017). Indonesia adalah Negara yang terkenal dengan adat ketimuran yang kental. Adat yang masih memegang teguh kesopanan sebagai hal utama dalm berinteraksi antar masyarakat. Oleh karena itu, adat kesopanan ini perlu terus dilestarikan sebagai budaya bangsa Indonesia dimata dunia. Kasuskasus yang marak muncul saat ini, seperti kasus perbuatan asusila, pencurian, penganiayaan dan lain sebagainnya yang berhubungan. Moral adalah proses internalisasi norma-norma masyarakat seiring dengan kematangan biologis seseorang. Perbuatan asusila, mencuri, dan menganiaya adalah perbuatan yang bertentangan dengan norma masyarakat karena dianggap sudah melanggar aturan-aturan dalam masyarakat dan merugikan orang lain. Seseorang dianggap telah mengembangakan aspek moral jika telah menginternalisasi aturanaturan atau kaidah-kaidah serta dapat mengaktualisasikan dalam kehidupan bermasyarakat secara terus menerus. Adat istiadat kesopanan merupakan bagian dari aspek moral. Agar aspek moral dapat tertanam dengan baik hingga dewasa, maka pengembangannya perlu diberikan sejak dini. Salah satu usaha untuk mengoptimalkan perkembangan moral pada anak untuk mencapai kematangan adalah melalui kegiatan mendongeng. Kegiatan mendongeng ini juga dapat dilakukan sebagai pengantar tidur anak ketika di rumah. Karena ketika tidur penanaman moral yang diberikan akan terekam dengan baik.

Berbeda halnya dengan di sekolah. Kegiatan mendongeng sangat di sukai anak. Apalagi jika guru dalam membawakan cerita dongeng disertai dengan mimik wajah dan suara yang sesuai dengan isi dongeng. Akan lebih baik lagi jika guru menggunakan media audiovisual ketika mendongeng. Penggunaan media audio visual dalam pembelajaran sangatlah efektif karena sangat menghemat tenaga bagi pengajar dan juga menumbuhkan semangat belajar anak karena proses pembelajaran akan menjadi menarik dengan adanya gambar-gambar atau video yang dapat dilihat sebagai contoh dari teori pembelajaran yang dijelaskan oleh guru. Ketika pembelajaran tidak menggunakan media ini maka ketika guru menjelaskan tentang penjabaran suatu pelajaran, sebagai contoh menceritakan dongeng pada anak, maka si anak akan mengahayal kesana kemari untuk membayangkan bagaimana visual atau tampak nyata dari dongeng tersebut. Namun jika menggunakan media audio visual maka siswa atau anak akan langsung melihat bagaima demo gambar atau video dari cerita dongeng tersebut. Maka diharapkan melalui aktifitas mendongeng, moral-moral baik dapat diperkenalkan.

\section{DONGENG}

Dongeng merupakan bentuk sastra lama yang bercerita tentang suatu kejadian yang luar biasa penuh khayalan (fiksi) yang dianggap oleh masyarakat suatu hal yang benar-benar terjadi. Asal mula dongeng terbagi atas dua teori yaitu (1). Dongeng berasal dari satu sumber dan menyebar dari satu budaya ke budaya yag lain dari waktu ke waktu. Teori ini menggambarkan bahawa dongeng menjadi sebuah tradisi tutur yang disampaikan secara turun temurun oleh nenek moyang kita dari abad ke abad; dan (2). Teori yang mengacu pada referensi pengalaman tutur umat manusia dan tradisi tulis sejak zaman mesir kuno. Menurut teori ini, dongeng yang ditulis berasal dari mesir kuno dan sekitar 1300 SM. Teori ini seolah ingin menyebutkan secara eksplisit berdasarkan fakta sejarah yang sudah terjadi beberapa abad yang silam.

Huck, Hepler, dan Hick- man (1987), dongeng adalah segala bentuk narasi baik itu tertulis atau oral, yang sudah ada dari tahun ke tahun. "all forms of narrative, written, or oral, which have come to be handed down through the years". Jadi, dongeng adalah segala bentuk cerita-cerita yang sejak dulu sudah ada dan diceritakan secara turun-temurun. Priyono dalam Ardini (2012) dongeng adalah cerita khayalan atau cerita yang mengada-ada serta tidak masuk akal dan dapat ditarik manfaatnya. Jadi, cerita yang terdapat di dalam dongeng adalah cerita khayalan yang terkadang di luar akal sehat. Seperti, cerita Timun Mas ketika menebar biji buah timun yang seketika berubah menjadi hutan lebat. Walau- pun cerita dongeng tidak masuk akal tetapi cerita dalam dongeng memiliki informasi yang dapat ditarik manfaatnya. Seperti, pesan moral agar menghormati dan menyayangi orang tua pada kisah Malin Kundang atau cerita Roro Jograng 
yang berkisah tentang asal mula berdirinya Candi Prambanan.

Sanchez dkk dalam Ahyani (2010) mengungkapkan bahwa kekuatan utama strategi dongeng adalah menghubungkan rangsangan melalui pengambaran karakter. Dongeng memiliki potensi untuk memperkuat imajinasi, memanusia akan individu, meningkatkan empati dan pemahaman, memperkuat nilai dan etika, dan merangsang proses pemikiran kreatif/kritis.

Mizan dalam Mubarokah (2015) Dongeng adalah cerita rekaan, khayalan yang dianggap tidak benar-benar terjadi, terdapat beberapa aspek didalamnya yaitu aspek intelektual, aspek kepekaan, kehalusan budi, emosi, seni, fantasi dan imajinasi, tidak hanya mengutamakan otak kiri, tapi juga otak kanan.

Dongeng sebuah karya sastra tentunya memuat banyak cerita dengan berbagai tema cerita dan karakter tokoh utama yang berbeda-beda. Dongeng kadang menceritakan sebuah cerita yg menggambarkan tokoh durhaka, baik, lucu, cerdik dan lain-lain. Pemilihan dongeng yang akan diceritakan sangat mempegaruhi ketertarikan pendengar, tujuan pembacaan dongeng dan pembelajaran apa yang akan dipetik dari dongeng tersebut.

\section{KEGIATAN MENDONGENG}

Mendongeng merupakan kegiatan mencerikan dongeng pada audiens atau pendengar. Mendongeng biasa dilakukan orang tua sebagai pengantar tidur untuk anak. Namun selain itu, dongeng dapat pula dijadikan mata pelajaran di sekolah sekolah tingkat dasar seperti TK/RA, PAUD ataupun tingkat sekolah dasar (SD). Masa kanak-kanak merupakan masa yang paling penting untuk sepanjang usia hidupnya. Sebab masa kanak-kanak adalah masa terbentuknya fondasi dan dasar kepribadian yang akan menentuan kehidupan anak selanjutnya. Karena pengalaman yang dialami anak usia dini akan berpengaruh dan bertahan lama, bahkan tidak dapat terhapus. Di dalam dongeng terdapat moral dan nilai bangsa yang sesuai dengan keadaan masyarakat Indonesia. Jadi dongeng sendiri adalah sarana pendidikan moral bangsa yang sesuai. Selain bahasanya mudah dicerna, tokoh dalam dongeng dapat melambangkan sifat manusia dalam kehidupan sehari hari.

Secara komitmen pendidikan anak usia dini tertuang dalam UU No. 23 Tahun 2002 tentang Perlindungan Anak pasal 4 menyatakan bahwa setiap anak berhak memperoleh pendidikan dan pengajaran dalam rangka pengembangan pribadinya dan tingkat kecerdasannya sesuai dengan minat dan bakatnya.

Isbel dkk (2004) menegaskan mendongeng mempunyai banyak kegunaan di dalam pendidikan utama anak. Dia menyimpulkan bahwa dongeng menyediakan suatu kerangka konseptual untuk berpikir, yang menyebabkan anak dapat membentuk pengalaman menjadi keseluruhan yang dapat mereka pahami. Dongeng menyebabkan mereka dapat memetakan secara mental dan pengalaman dan melihat gambaran dalam kepala mereka, mendongengkan dongeng tradisional menyediakan anak suatu model bahasa dan pikiran bahwa mereka dapat meniru (Ahyani, 2010).

Berdasaran survei yayasan amal, Booktrust, terhadap 1000 orangtua, ditemukan bahwa pasangan suami istri muda dengan kisaran usia 16 hingga 24 tahun, memiliki rasa percaya diri yang rendah ketika membacakan buku untuk anak-anak mereka. Survei menunjukkan hanya $28 \%$ orangtua berusia muda yang memiliki ritual membaca buku bersama anak sebelum waktu tidur malam. Angka tersebut cenderung rendah dibandingkan $42 \%$ persen orangtua berusia matang yang membacakan buku untuk anak. Menurut laporan survei, kondisi buruk ini jelas terlihat pada kaum ayah yang berusia di bawah 25 tahun. Sebab, hanya $19 \%$ yang mengaku masih membacakan buku untuk anak. Sementara itu, ayah yang berusia lebih dari 25 tahun hingga 55 tahun, sebanyak $78 \%$ mengatakan bahwa mereka terus membudayakan tradisi membaca sebelum tidur pada anak-anak (National Geographic Indonesia, 2016).

Rendahnya akifitas orang tua dalam pembelajaran membacakan dongeng mengakibatkan semakin tidak dikenalnya dongeng oleh anak-anak masa sekarang dan masa mendatang. Dengan fenomena seperti ini dongeng semakin terlupakan sebagai sebuah karya seni bangsa yang seharusnya sangat kental dengan masyarakat Indonesia. Oleh karena itu diharapkan kepada masyarakat untuk mulai membacakan atau memperkenalkan dongeng pada anak-anak sejak dini, karena tujuannya bukan hanya untuk melestarikan budaya tapi juga memberikan banyak pembelajaran yang dapat dipetik dari dongeng. 


\section{PENDIDIDIKAN MORAL PADA ANAK USIA DINI}

Kaelan (2002) berpendapat moral yaitu suatu ajaran-ajaran atau wejangan-wejangan, patokan-patokan atau kumpulan peraturan baik lisan maupun tertulis tentang bagaimana manusia yang baik. Hendrowibowo (2007) moral adalah sikap hati yang terungkap dalam lahiriah. Moralitas terjadi jika seseorang mengambil sikap yang baik, karena ia sadar akan tanggung jawabnya sebagai manusia. Jadi moralitas adalah sikap dan perbuatan baik sesuai dengan nurani (Kusrahmadi, 2007).

Dalam berbagai argumen lain juga mengatakan moral merupakan perubahan penalaran, perasaan, dan perilaku tentang standar mengenai benar salah. Standar benar dan salah yang mengatur perubahan penalaran, perasaan dan perilaku ini tumbuh berdasarkan perkembangan lingkungan sekitar tempat individu tinggal. Sehingga moral dapat juga dikatakan sebagai adat atau kebiasaan. Selain itu moral juga dikatakan sebagai peraturanperaturan.

Berdasarkan beberapa pengertian moral diatas dapat disimpulkan bahwa moral merupakan kondisi pikiran, perasaan, ucapan, dan perilaku manusia yang terkait dengan nilainilai baik dan buruk.

Moral (bahasa latin moralitas) adalah istilah manusia menyebut ke manusia atau orang lainnya dalam tindakan yang mempunyai nilai positif. Manusia yang tidak memiliki moral disebut amoral, artinya dia tidak bermoral dan tidak memiliki nilai positif pada kacamata manusia lainnya. Sehingga moral adalah hal mutlak yang harus dimiliki oleh manusia. Moral secara ekplisit adalah hal-hal yang berhubungan dengan proses sosisalisasi individu, tanpa moral manusia tidak dapat melakukan sosialisasi. Moral pada zaman sekarang ini mempunyai nilai implisit karena banyak orang yang tidak mempunyai moral atau sikap amoral itu dari sudut pandang yang sempit. Moral adalah sifat dasar yang diajarkan disekolah-sekolah dan manusia harus mempunyai moral jika ia ingin dihormati oleh sesamanya. Moral keabsolutan dalam kehidupan bermasyarakat secara utuh. Penilaian terhadap moral diukur dari kebudayaan masyarakat setempat. Apabila yang dilakukan seseorang itu sesuai dengan nilai rasa yang berlaku dimasyarakat tersebut dan dapat diterima serta menyenangkan lingkungan masyarakatnya. Maka orang itu dinilai mempunyai nilai moral yang baik, begitu pula sebaliknya (Ardini, 2012).

Pendidikan moral usia dini merupakkan sesuatu yang sangat vital terutama untuk pembentukkan perilaku anak diusia dewasa, maka di usia dini inilah dasar pembentukkan perilaku anak perlu di perhatikkan. Pembimbingan dan teladan dari sosok orang tua merupakkan cara paling efektif bagi anak di usia dini, karena dilihat dari faktor kedekatan dan ketergantungan anak salah satu cara untuk memberikan contoh yang bertujuan agar anak mengikuti perilaku tersebut, karena pada dasarnya anak usia dini mempunyai kecenderungan sebagai 'Peniru' dari apa yang dilihatnya. Dari segi itulah pembentukkan moral anak di mulai dari lingkungan keluarga yang memiliki peran yang sangat vital. Sebagai orang tua alangkah baiknya jika anak yang masih dalam usia dini perlu untuk di kenalkan dengan kebiasaan yang baik, sepert : di latih dengan selalu menggunakkan bahasa yang sopan, di kenalkan dengan tata cara beribadah, pergi ke masjid dll.

Selain pendidikan moral yang mulai dibekali dalam lingkungan keluarga juga perlu adanya keseimbangan yaitu dengan mengenalkan lingkungan sekitar yang tetap dalam pelaksaannya selalu didampingi oleh orang tua agar perkembangan dan kegiatannya selalu dalam perhatian orang tua, secara tidak langsung proses pengenalan terhadap lingkungan sekitar membuat anak akan selalu membandingkan antara kebiasaan yang diterapkan di lingkungan keluarga dengan perilaku teman-temanya di lingkungan sekitar, disitu peran orang tua menjadi jembatan antara anak dan lingkungan sekitar dengan seringnya pertanyaan yang di ajukkan oleh anak kepada orang tua, kenapa, kok bisa, dan bagaimana. Pertanyaan seperti itu yang sering di terima oleh orang tua, karena seorang teman mempunyai latar belakang sendiri tentu saja tidak lepas dari pendidikan moral orang tuanya.

Usia dini erat hubungannya dengan dunia bermain, maka sebaiknya orang tua melakukan pendidikan moral disini yaitu dengan memberikan mainan yang berhungan dengan moral dan etika yang baik, serta perilaku juga harus selalua diperkenalkan kepada anak. Dari mainan yang ada kaitanya dengan moral seperti dari segi agama mainan puzzle yang membentuk tulisan Asma Allah SWT dan masih banyak lagi. Dari segi bemain saja bisa kita arahkan anak menuju pembentukkan moral yang baik, melalui 
permainan anak lebih cenderung menerima pola pendidikan moral karena pada dasarnya usia dini gemar bermain.

Pada usia dini, anak sebaiknya dilatih dengan sikap disiplin, dengan pengenalan disiplin anak belajar mengatur dirinya sendiri, pada awalnya anak akan mengalami kesulitan tapi pada akhirnya disiplin ini akan membantu dia pada waktu dewasa, dan mengerti apa yang harus dia lakukan serta akan muncul sikap kemandirian.

Penanaman nilai-nilai moral sejak dini sangatlah bermanfaat bagi perkembangan anak. Agar dia mampu menjadi anak yang baik dimasa depan nanti. Dan tidak mudah terpengaruh oleh pergaulan luar yang sudah sangat bebas dan terbuka sekali. Apalagi, internet pun sudah sangat mudah diakses. Perlunya perhatian orang tua disaat-saat anak usia balita sampai dimana dia mampu menjadi diri nya sendiri (menemukan jati diri nya).

Banyak sekali metode-metode yang dapat dilakukan untuk menanamkan nilai-nilai moral pada anak usia dini. Misalnya a) Dengan memberikan contoh yang digambarkan dengan dongeng, b) Dengan bercerita, c) dll.

\section{DONGENG SEBAGAI PEMBELAJARAN MORAL PADA ANAK USIA DINI}

Pendidikan masa awal kanak-kanak ditantang untuk memperkenalkan anak-anak kepada dunia untuk masa depan mereka, suatu dunia yang akan terus meningkat menjadi multicultural dan bersuku banyak. Metode dongeng adalah suatu alat kuat untuk meningkatkan suatu pemahaman diri dan orang lain. Aktivitas mendongeng juga dapat memberikan banyak nilai positif bagi yang mendengarkan juga si pembaca dongeng terutama pembelajaran moral.

Staden \& Waston (2007) mendongeng mempunyai kemampuan untuk menciptakan lingkungan belajar yang benar untuk anak usia dini. Selain itu metode dongeng dapat dijadikan sebagai media membentuk kepribadian dan moralitas anak usia dini. Menurut Borba (2001) dongeng tentang suatu kebajikan serta pengaruhnya dalam memberikan perubahan yang positif di dunia akan membantu anak memahami suatu kekuatan kebajikan tersebut dan membuat mereka berpikir mereka pun dapat melakukan segala sesuatu bagi dunia. Menurut pandangan lain dari Staden \& Watson dongeng mempunyai kemampuan untuk menciptakan lingkungan belajar yang benar untuk siswa anak usia dini. Selain itu, metode dongeng dapat dijadikan sebagai media membentuk kepribadian dan moralitas anak usia dini (Ahyani, 2010). Menurut pandangan Sulityorini dalam Fitroh dan Sari (2015) menyatakan bahwa penyadaran nilai moral anak sangat tepat jika dilakukan melalui cerita atau dongeng, sebab cerita atau dongeng merupakan media efekktif untuk menanamkan nilai dan estetika kepada anak.

Dari empat pendapat ahli diatas telah dijelaskan bahwa dongeng merupakan sarana pembelajaran moral yang sangat baik dalam memberikan pemahaman pada anak-anak untuk memahami bagaimana seharusnya mereka bersikap dengan moral yang baik. Metode dongeng memiliki sejumlah aspek yang diperlukan dalam perkembangan kejiwaan anak, memberikan wadah pada anak untuk belajar berbagai emosi dan perasaan serta belajar nilainilai moral. Anak akan menirukan hal-hal baik yang diperankan oleh sang tokoh, juga dapat dijadikan suatu percontohan untuk dirinya dalam pembentukan dirinya. Dalam dongeng pula anak dapat belajar hal-hal apa saja yang seharusnnya tidak boleh dilakukan atau diperbuat karena suatu hal yang tidak baik akan memiliki ganjaran tertentu, "contoh pada tokoh dongeng Malin Kundang yang telah durhaka pada ibunya karena setelah sukses, dia sudah tidak mau mengakui ibunya yang miskin. Akhirnya ibunya berdoa semoga dia dibalas oleh Yang Maha Kuasa hingga dia di kutuk menjadi batu".

Dalam kutipan dongeng di atas anak dapat dengan mudah memahami bahwa seorang anak tidak boleh durhaka pada orang tuanya. Dalam aspek lain dari dongeng anak-anak dapat langsung memahami bagaimana moral bangsa yang sebenarnya karena dongeng berasal dari cerita-cerita kedaerahan berasal dari bangsa Indonesia, sehingga nilai dan norma yang terdapat di dalam dongeng merupakan nilai dan norma yang harus dipatuhi oleh bangsa Indonesia itu sendiri.

Dongeng merupakan media yang sangat efektif untuk menanamkan berbagai nilai dan etika terhadap anak. Termasuk menimbulkan rasa empati dan simpati anak. Nilai-nilai yang bisa dipetik dari dongeng adalah nilai kejujuran, kerendah hatian, kesetiakawanan, kerja keras, dan lain sebagainya. Bagi anak-anak usia dini, ternyata mendongeng masih tetap selalu dinantikan. Cerita atau dongeng adalah salah satu media komunikasi guna menyampaikan beberapa pelajaran atau pesan moral kepada 
anak. Selain itu, tentu saja, metode-metode pembelajaran lainnya yang pada saat ini telah menggunakan teknologi canggih yang menarik untuk para peserta didik.

Telah terbukti bahwa menyampaikan pembelajaran dengan cara mendongeng pun tak kalah menariknya bila dibandingkan dengan pembelajaran melalui alat peraga atau alat bantu teknologi canggih. Pesan moral dapat dengan mudah disampaikan kepada anak melalui sebuah cerita atau dongeng. Tidak ada batasan usia kapan anak mulai boleh mendengarkan dongeng. Anak-anak usia prasekolah dapat mendengarkan cerita sederhana tentang hewan.

Mendongeng bisa menjadi aktivitas berkomunikasi dengan anak yang mudah dan murah. Di samping itu, mendongeng juga bisa menjadi sarana efektif dalam menyampaikan pesan pada anak. Anak tidak merasa dinasehati atau digurui oleh orang tua/pendidik karena tercipta suasana menyenangkan. Anak pun diposisikan sebagai subyek aktif yang ikut bermain peran dan/atau melibatkan seluruh inderanya untuk larut dalam cerita. Materi dongeng dapat diambil dari buku cerita anakanak yang memuat pesan moral atau dari kejadian sehari-hari yang berlangsung di sekitar lingkungan tinggal anak. Kegiatan mendongeng juga akan menumbuhkan kecintaan anak pada buku karena anak menemukan banyak hal positif yang bisa diperoleh dengan membaca buku. Dongeng bisa berpengaruh pada perkembangan fisik, intelektual, dan mental anak. Ini dikarenakan keterlibatan seluruh indera anak ketika mendengarkan dongeng. Kecerdasan kognitif anak terasah lewat keterampilan berimajinasi dan menyimpulkan makna yang terkandung dalam cerita dongeng. Keterlibatan secara aktif dalam aktivitas dongeng akan memberikan pengalaman konkret pada anak sehingga akan tertanam kuat dalam struktur kognitif anak.

Namun ada hal yang perlu diperhatikan dalam pemilihan dongeng untuk disajikan pada anak seperti pendapat Hendri (2013) bahwa pentingnya memiliki kemampuan yang tajam dalam memilih cerita yang tepat untuk anak, menjadi sesuatu yang wajib. Tanpa memiliki kemampuan memilih, dikhawatirkan anak-anak bangsa ini malah semakin terpuruk. Selain kemampuan memilih, kepandaian merekonstruksi sekaligus mengemas cerita menjadi cerita yang menarik dan memiliki daya didik yang luar biasa menjadi keharusan tersendiri baik orang tua maupun guru.
Dongeng berpotensi memberikan sumbangsih besar bagi anak sebagai manusia yang memiliki jati diri yang jelas, jati diri anak ditempa melalui lingkungan yang diusahakan secara sadar dan tidak sadar. Dongeng dapat digunakan sebagai sarana mewariskan nilai-nilai luhur kepribadian. Secara umum dongeng dapat membantu anak menjalani masa tumbuh kembangnya. Anak-anak dapat memahami pola drama kehidupan melalui tokoh dongeng. Melalui dongeng, anak-anak akan terlibat dalam alur cerita dongeng dalam hal ini anak-anak menumbuhkembangkan intelektualitasnya. Dongeng mampu membawa anak melanglangbuana, memasuki dunia fantasi, menyeret mereka ke dunia antah-berantah dan membayangkan berbagai "kehidupan lain" yang tidak ada di dekat mereka, dalam hal ini dapat menumbuhkan dan menggerakkan daya ciptanya.

\section{PENGGUNAAN MEDIA AUDIO VISUAL DALAM PEMBELAJARAN MORAL MELALUI DONGENG}

Tidak dapat dipungkiri lagi bahwa penggunaan media pembelajaran erat kaitannya dengan perkembangan ilmu pengetahuan dan teknologi (IPTEK). Perkembangan IPTEK semakin mendorong upaya-upaya pembaharuan dalam pemanfaatan hasil-hasil teknologi dalam proses belajar. Teknologi paling tua yang dimanfaatkan dalam proses belajar adalah sistem percetakan yang bekerja atas dasar fisik mekanik. Kemudian lahir teknologi audio visual yang menggabungkan penemuan mekanik dan elektronik untuk tujuan pembelajaran. Selain teknologi media audio visual masih ada lagi teknologi multimedia yang sering kali digunakan dalam pembelajaran. Lahirnya teknologi multimedia adalah hasil dari perpaduan kemajuan teknologi elektronik, teknik komputer dan perangkat lunak. Kemampuan penyimpanan dan pengolahan gambar digital dalam belasan juta warna dengan resolusi tinggi serta reproduksi suara maupun video dalam bentuk digital. Multimedia merupakan konsep dan teknologi dari unsur unsur gambar, suara, animasi serta video disatukan didalam komputer untuk disimpan, Diproses dan disajikan guna membentuk interaktif yang sangat inovatif antara komputer dengan user. Dengan banyaknya variasi media pembelajaran ini, perlu kita ketahui bahwa tidak 
ada satu media pun yang paling baik. Setiap media memiliki keunggulan dan kelemahan masing-masing. Oleh karena itu penting bagi guru untuk memahami setiap media pembelajaran, mulai dari karakteristik tiap-tiap media pembelajaran hingga faktor-faktor yang mempengaruhi penggunaan media pembelajaran tersebut.

Menurut Wingkel (2009) media audio visual adalah media kombinasi antara audio dan visual yang diciptakan sendiri seperti slide yang dikombinasikan dengan kaset audio. Selanjutnya, menurut Wina Sanjaya(2010), media audio visual adalah media yang mempunyai unsur suara dan unsur gambar yang bisa dilihat, misalnya rekaman video, slide, suara, dan sebagainya. Penggunaan media audio visual dalam pembelajaran sangatlah efektif karena sangat menghemat tenaga bagi pengajar dan juga menumbuhkan semangat belajar sisiwa karena proses pembelajaran akan menjadi menarik dengan adanya gambar-gambar atau video yang dapat dilihat sebagai contoh dari teori pembelajaran yang dijelaskan oleh guru. Ketika pembelajaran tidak menggunakan media ini maka ketika guru menjelaskan tentang penjabaran suatu pelajaran, sebagai contoh menceritakan dongeng pada anak, maka si anak akan mengahayal kesana kemari untuk membayangkan bagaimana visual atau tampak nyata dari dongeng tersebut. Namun jika menggunakan media audio visual maka siswa atau anak akan langsung melihat bagaima demo gambar atau video dari cerita dongeng tersebut.

Hal tersebut seperti dijelaskan dalam pendapat Themistoklis Semenderiadis, (2009: 68) media audio visual memberikan peran penting dalam proses pendidikan, terutama ketika digunakan oleh guru dan siswa. Media audio visual memberikan banyak stimulus kepada siswa, karena sifat audio-visual/suara gambar memperkaya lingkungan belajar, memelihara eksploitasi, eksperimen dan penemuan,dan mendorong siswa untuk mengembangkan pembicaraan dan mengungkapkan pikirannya. Seperti yang diungkapkan Atoel (2011: 20), media audio visual meiliki beberapa kelebihan dan keunggulan diantaranya : 1) Memperjelas penyajian pesan agar tidak terlalu bersifat verbalitas (dalam bentuk kata, tertulis atau lisan); 2) Mengatasi keterbatasan ruang, waktu, dan daya indara, seperti objek terlalu besar digantikan dengan realitas, gambar, film bingkai atau model; 3) Media audio visual berperan dalam pembelajaran tutorial (Purwono, dkk, 2014).

Dalam pelajaran dongeng dengan tujuan menyampaikan pembelajaran moral pada anak akan lebih mudah jika menggunakan media pembelajaran audio visual karena dapat meningkatkan pemahaman tentang pesan-pesan moral yang diberikan. Dengan media pembelajaran audio visual juga siswa dapat lebih aktif, kreatif dan antusias ketika berlangsungnya proses pembelajaran. Dari segi ketertarikan anak terhadap pelajaran akan lebih tinggi, karena pada umumnya anak-anak akan suka melihat gambar daripada hanya melalui cerita. Misalkan dongeng yang ditampilkan merupakan video dongeng yang berbentuk animasi (kartun). Penggunaan media audio visual ini juga dapat membantu memberikan konsep pertama atau kesan yang benar, mendorong minat, meningkatkan pemahaman yang lebih baik, melengkapi sumber belajar yang lain, menambah variasi metode mengajar, menghemat waktu, meningkatkan keingintahuan intelektual, cenderung mengurangi ucapan dan pengulangan kata yang tidak perlu, membuat ingatan terhadap pelajaran lebih lama, dapat memberikan konsep baru dari sesuatu diluar pengalaman.

Hal ini sesuai dengan pendapat Oemar Hamalik (dalam Musfiqon 2012: 32), bahwa pemakaian media pembelajaran dalam proses belajar mengajar dapat membangkitkan keinginan dan minat yang baru, membangkitkan motivasi dan rangsangan kegiatan belajar, dan bahkan membawa pengaruh-pengaruh psikologis terhadap anak.

Pesan pembelajaran yang disampaikan guru tanpa menggunakan media akan terasa hambar dan tidak akan membekas jika tidak menggunakan media. Juga pendapat lain dari Musfiqon (2012 : 187) mengemukakan bahwa pembelajaran yang menggunakan multimedia telah terbukti lebih efektif dan efisien serta bisa meningkatkan hasil belajar siswa.

\section{PENUTUP}

Aktivitas mendongeng menggunakan media audio visual pada pembelajaran moral sangatlah efektif karena penggunaan media ini dapat mempermudah proses pembelajaran yang sebelumnnya guru harus bercerita kepada anak atau siswa untuk menyampaikan dongeng. Dengan adanya media audio visual maka guru tidak perlu lagi bercerita lagi karena dongeng yang akan disampaikan telah berbentuk video, 
anak atau siswa tinggal menonton dan kemudian guru menuntun untuk memahami pesan-pesan moral yang terdapat dalam dongeng jika belum dipahami. Penggunaan media audio visual ini juga mampu meningkatkan ketertarikan anak untuk belajar.

Metode dongeng sebagai stimulasi berperan dalam meninkatkan perkembangan kecerdasan moral anak dinilai sangat efektif dalam memberikan pelajaran moral maka diharapka penggunaan metode dongeng dapat dilakukan secara berkelanjutan untuk menyampaikan nilai-nilai moral agar perkembangan kecerdasan moral anak terus meningkat.

Menerapkan metode mendongeng dengan memanfaatkan kemajuan teknilogi ini selain akan mempercepat proses pembelajaran juga mempermudah proses pelestarian budaya bangsa yang hampir terlupakan seiring perkembangan zaman. Maka dengan itu kita coba untuk memanfaatkan perkembangan zaman untuk kembali melestarikannya.

\section{DAFTAR PUSTAKA}

Ardini, Pupung Puspa. 2012. Pengaruh Dongeng Dan Komunikasi Terhadap Perkembangan Moral Anak Usia 7-8 Tahun. Jurnal Pendidikan Anak, 1(1), 46-52.

Aryani, Latifah Nur. 2010. Metode Dongeng dalam Meningkatkan Perkembangan Kecerdasan Moral Anak Usia Dini, Jurnal Psikologi, 1 (1), 24-26.

Borba, M. (2001). Building moral intelligence. San Fransisco : Josey-Bass.

Isbell, R., Sobol, J., Lindauer, L\& Lowrance. (2004). The effects of storytelling and story reading on the oral language complexity and story comprehension of young children. Early childhood education journal, 32 (3). Springer Science Business Media, Inc.

Fitroh, Siti Fadjryana dan Evi Dwi Novita Sari. 2015. Dongeng Sebagai Media Penanaman Parakter Pada Anak Usia Dini. Jurnal Pg-Paud Trunojoyo, 2 (2).

Hendri, Kak.2013. Pendidikan Karakter Berbasis Dongeng. Bandung: Simbiosa Rekatama Media.

Hendrowibowo, I. 2007. Pendidikan Moral. Majalah Dinamika. FIP: UNY.
Huck, Charlotte S. dkk. 1987. Children Literature in the Elementary School.USA : Holt, Rinehart and Winston Inc.

Kapan lagi. 2017. Fenomena Klitih, Potret Kenakalan Remaja Yang Mengkhawatirkan. [Online]. Tersedia: https://plus.kapanlagi.com/fenomenaklitih-potret-kenakalan-remaja-yangmengkhawatirkan-f90439.htmL. [ 2 Desember 2017].

Kaelan. 2001. Pendidikan Moral Dan Pancasila. Yogyakarta:Paradigma.

Kusrahmadi, Sigit Dwi. 2007. Pentingnya Pendidikan Moral Bagi Anak Sekolah Dasar.Yogyakarta:UNY. [Online]. Tersedia: http://eprints.uny.ac.id/5006/1/pentingn y_a_pendidikan_moral.pdf.[3 Desember 2017].

Musfiqon. 2012. Pengembangan Media \& Sumber Pembelajaran. Jakarta. Prestasi Pustaka Raya.

Mubarokah, Baniyatul. 2015. Penerapan Metode Dongeng Dalam Pembelajaran Bidang Pengembangan Akhlak Dan Nilai-Nilai Agama Islamdi Pendidikan Anak Usia Dini (PAUD) Tunas Islam Purwokerto. Skripsi. Pendidikan Agama Islam, Institut agama Islam Negeri (IAIN) Purwokerto.

National Geographic Indonesia. 2016. Tradisi Baca Buku Dengan Anak Sebelum Tidur Makin Punah. [Online]. Tersedia: http://nationalgeographic.co.id/berita/20 16/06/tradisi-baca-buku-dengan-anaksebelum-tidur-makin-punah. [ 5 Desember 2017]

Priyono, Kusumo. $2006 . \quad$ Terampil Mendongeng. Jakarta : Grasindo.

Purwono, Joni, dkk. 2014. Penggunaan Media Audio-Visual Pada Mata Pelajaran Ilmu Pengetahuan Alam Di Sekolah Menengah Pertama Negeri 1 Pacitan. Jurnal Teknologi Pendidikan dan Pembelajaran, 2 (2), 130-131.

Sanchez, T, Zam, G., Lambert, J. 2009. StoryTelling As An Effective Strategy In Teaching Character Education In 
Jurnal Smart PAUD, Vol. 1, No. 1, Januari 2018

Afifah Nur Hidayah \& Nurhadija

Middle Grade Social Studies. Journal for the liberal arts and sciences, 13 (2).

Staden, CJS. \& Watson, R. 2007. When old is new : exploring the potential of using indigenous stories to construct learning inearly childhood settings. A paper presented at the AARE conference, Fremantle 26-29th November.

Themistoklis Semenderiadis, 2009. Using audiovisual media in nursery school within the framework of the interdisciplinary approach. Synergies Sud-Est européen n ${ }^{\circ} 2$ - 2009

Wingkel, 2009. Psikologi Pengajaran. Yogyakarta: Media Abadi.

Wina, Sanjaya. 2010. Strategi Pembelajaran Berorientasi Standar Proses Pendidikan. Jakarta: Kencana

Wikipedia. 2017. Dongeng. [Online]. Tersedia: www.wikipedia.co.id/pengertian +donge ng. [8 Desember 2017]. 